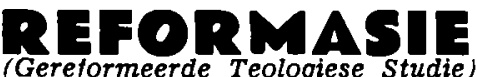

\section{GODDELIKE SOEWEREINITEIT EN MENSLIKE VERANTWOORDELIKHEID.}

\section{INLEIDEND:}

Ons moet inleidend stel dat ons hier te doen het met ' $n$ grootse misterie en dat dit vir ons gedagtes 'n beperking inhou. Hoe kan ons die almagtige God se soewereiniteit begryp? Hoe kan ons dit rym, dit in verhouding stel tot menslike verantwoordelikheid? Ons kan tog alleen in verhoudinge en verbande spreek.
Herman Bavinck begin sy behandeling oor God in sy bekende Gereformeerde Dogmatiek met hierdie duidelike woorde: „Het mysterie is het levenselement der dogmatiek .... Reeds terstond bij het begin van haar arbeid staat zij voor den Onbegrijpelijke". (II p.1).

Wanneer ons nou gaan spreek oor die werk van God met die sondaarmens, 
het ons nie net te doen met die onbegryplikheid van God nie, maar ook nog met die misterie van genade, waardeur God Homself stel in 'n bepaalde verhouding tot ons, 'n verhouding van liefde. Hoe kan die mens dan voor God staan? Onmiddellik verdwyn of liewer verdwerg die mens. As hy sou verdwyn, ken daar geen sprake meer wees van sy verantwoordelikheid nie. Maar en dit is genade - God vernietig nie die mens nie, ook nie die sondige mens nie. Gods hele openbaring is genadeopenbaring wat om die mens gaan. Die mens hoor, neem aan, word bevestig. Daar kom in hom 'n geloofsverband; hy is dankbaar. Op die wyse bevestig die Skrif dat God die mens tot lewe wek, hom aktiveer en 'n verklanker laat word van sy genadewerking.

Ons wil hier probeer om uit die Skrif en ons belydenisskrifte veral 'n tekening te gee van twee blikrigtinge in die dogmatiese denke onder Gereformeerde teoloë. Hierdie twee persone was tydgenote: Kuyper en Bavinck. Elkeen het 'n eie visie en 'n eie standpunt. In hul eie gedagteloop sien ons 'n stryd wat in die Gereformeerde kerke twee rigtinge was en gedurende 'n lang tyd so gebly het. Berkouwer beweer dat vanuit die 17 de eeu die kernmomente van die stryd ons teëkom in die Supra- en Infralapsarisme, en albei het vandag nog hul verdedigers. In verskillende nuanseringe het die gedagtestryd voortgegaan, telkens met ander nadruk, maar saaklik het dit altyd dieselfde gebly.

Dit gaan om die genadeverbond en sy verband tot die uitverkiesing. Dit gaan om die mens se aanvaarding van die beloftes. Die geloof: moet dit voor- waarde wees van die verbond of is dit met die verbond meegegee? En die bondelinge: moet hulle kollektiwisties gesien word, almal wat in die verbond gebore is, of het ons hier 'n partikuliere karakter met kondisionele voorbehoud?

Wat die probleem geensins vergemaklik nie, is dat ons hier met verhoudinge te doen het en diegene wat in verhouding tot mekaar staan, hef eintlik die bestaan van 'n verhouding op, maak dit ondenkbaar. Dink $u$ in: God staan in verhouding tot die mens. God stel Homself in ' $n$ bepaalde verhouding tot 'n verderflike sondige mens. God begin die verhouding en bied nie slegs die liefdesverhouding, die verbondsverhouding aan nie, maar neem die sondaarmens in die verhouding op.

Nou kan ons wel begryp dat dit alles goed gaan met ons gedagtes solank as wat die Goddelike inisiatief hier bly en alles enkel Gods daad is. Maar sodra as die tweeledigheid van die verbond na vore kom en ons begin dink aan sondigmenslike aktiwiteit, dat ons so 'n verhouding wat God aanbied kan aanvaar - en as ons dit kan aanvaar, kan ons dit ook laat vaar - kom die probleem in sy volle skerpte na vore.

Die vraag is wel of die dogmatiese denke die oplossing moet gaan soek in die locus de Deo of in die locus de sacra scriptura; is dit 'n saak wat benader moet word deur die verhouding van God tot die sondige mens in studie te neem, of moet ons die weergawe van daardie verhouding in die Heilige Skrif ontleed? Dit is tog immers die enigste plek waar ons van Gods verhouding tot die sondige mens lees. Maar die weergawe daarvan: is dit sodanig dat ons 
moet sê dat dit ons inlei om die reine goddelike weg met ons te verstaan? Of moet ons sê dat die Skrif in menslikverstaanbare trant tot ons spreek en dat ons versigtig moet wees om die skriftuurlike wyse van spreek nie toe te pas asof dit die Goddelike wyse van spreek weergee nie.

Hierdie aspek van die saak kan nie maklik opsy geskuif word nie. Ons is dikwels skerpsinnig genoeg om ons maklik af te maak van 'n sodanige probleem deur dit te bestempel as 'n antropomorfisme. Dink maar aan uitdrukkinge soos Goddelike berou, aan gebedsverhoring, aan Goddelike verandering na bekering. Ons kan skrifgedeeltes noem soos Ex. 32:9-14, waar die gebed van Moses 'n wending ten goede bring en Jona 3:10 waar bekering 'n wysiging bring in Gods voorgenome optrede. Hiervan sê Veldkamp mooi "In al deze en dergelijke gevallen blijkt, dat God op iets terugkomt, het spoor verlegt, iets ander doet dan $\mathrm{Hij}$ aanvankelijk voornemens was om te doen". En verder . . . ., dat God in zijn handelen volledig rekening houdt met de gedragingen van de mensen (Geref. Weekblad).

B. Wielenga wil ook nie weet van ontwyking van hierdie probleem nie. „Men zegge niet, dat God alleen Zijn gedragslijn en niet Zijn gezindheid veranderde". Ook Bavinck herinner daaraan dat ons nie net enkele antropomorfismes in die Skrif vind nie, maar „de gansche Schrift is anthropomorphistisch - als God tot ons sprak op goddelijke wijze, geen schepsel zou Hem verstaan" (Geref. Dogm. II p.68).

Ons kan begryp dat ernstige aandag gegee moet word aan die wyse waarop die Heilige Skrif Gods Raad in menslike verstaanbare taal aan ons weergee. Ons wil hier spreek oor Gods Raadsplan en wel soos Berkouwer dit uitdruk oor die "antwoordend handelen Gods" (De Voorzienigheid Gods, p.272). Ons moet spreek oor menslike verantwoordelikheid in verband met Gods soewereiniteit en kan dit alleen doen as ons rekening hou met hoe Gods Woord ons die handelinge van God ten opsigte van die mens laat sien. As dit gaan om die mens se ewige wel of wee, kan ons wel enkel spreek oor ewige handelinge van God: voorbeskikking, uitverkiesing, wedergeboorte. Maar die vraag is of alles dan nie verstar en word dit alles nie juis onbegryplik vir die mens nie. Die Skrif wil tog ons hier inskakel en laat ons sien dat dit nie alles buite ons om en tog wel om ons gaan nie, maar dat Gods handeling 'n antwoordende handeling is. Dit maak God dan nie minder nie, sekerlik nie afhanklik van ons geloof of berou nie, maar waarlik oneindig in genade en goedertierenheid.

$\mathrm{Na}$ hierdie inleiding wil ons nou histories aansluit by die bekende stryd tussen die Infra- en Supralapsarisme en daarna die worsteling met die probleem besien by Abraham Kuyper snr. en $\mathrm{H}$. Bavinck.

I. INFRA- EN SUPRALAPSARISME

Die geskiedenis van die Gereformeerde kerke leer dat daar telkens besondere belangstelling en ook verskille tot openbaring gekom het wat almal min of meer verband hou met een van hierdie genoemde twee rigtinge. Dit is waar dat Berkouwer hom die vraag stel of die bekende stryd tussen hierdie twee rig- 
tings nie terminologies al vreemd aan ons word nie. Berkouwer vra of so 'n teologie nie tot 'n gnosis geword het en dan in abstraksies verval en daarom die geloof van die gemeente nie meer wesenlik raak nie. . En dan word so 'n dogmatiek 'n blote akademiese paradeterrein en al wat die kerk daaruit kan verwag is versplintering. Die sake waarom dit hier werklik gaan is nie maar alleen interessant nie, is nie maar bedoel vir wetenskaplike navorsers nie, maar is vol heilige ewige lewenserns.

Die verskil tussen die twee rigtings moet nie soseer gesoek word in die tydsorde of die aspek van die volgorde wat betref predestinasie en val nie. Laat ons dit korteliks só stel: Het God eers besluit en daarna geskep? Of was die skepping en val eers en daarna Gods predestinasie? M.a.w. Is die voorwerp van predestinasie die homo creabilis et labilis - of is die voorwerp die homo creatus et lapsus?

Dijk stel die twee rigtinge duidelik in die volgende tabulering:-

INFRA: 1 . God besluit om Homself in die openbaring van sy deugde te verheerlik.

2. God besluit om die mens te skep en wel so dat hy kan val; en voorts om die val nie te verhinder nie.

3. Uit die gevalle mens besluit God om te verkies en te verwerp.

SUPRA: 1. God wil sy Naam verheerlik deur sy barmhartigheid en geregtigheid te openbaar.

2. Hy openbaar sy barmhartigheid en geregtigheid deur te verkies en te verwerp.
3. Om hierdie doel te bereik besluit God om die mens te skep en die val toe te laat.

Hier word dus deur Dijk vierderlei onderskeid aangegee:

A. By Infra is Gods doel om al sy deugde te openbaar.

By Supra gaan dit om die deugde van barmhartigheid en geregtigheid.

B. By Infra is die sonde in Gods besluit opgeneem.

By Supra is sonde 'n skakel en wel as middel tot 'n doel.

C. By Infra volg verkiesing en verwerping op skepping en val.

By Supra gaan verkiesing en verwerping daaraan vooraf.

D. By Infra in die voorwerp van die predestinasie die geskape en gevallene. By Supra is die voorwerp die te skeppe mens wat kan val.

Albei hierdie standpunte word begryplikerwys gedruk deur baie besware, om maar net één te noem: By Supra skyn dit asof God die Outeur van die sonde genoem sou kan word, omdat God die sonde ook in sy Raad opgeneem he ${ }^{\dagger}$ Ook Infra sal moet verklaar waarom God dan nie verhoed het dat die mens sondig nie. Daar is baie oplossings aan die hand gedoen, maar nie een het bevredig nie. Sommige wou spreek dat God nie die sonde in sy Raad opgeneem het nie, maar slegs 'n voorwete daarvan gehad het. Dus nie 'n predestinatio nie, maar wel praescientia.

Dit gaan hier om Gods soewereine handeling en die mens se verantwoordelikheid. Hier kan die menslike verantwoordelikheid alleen nog maar van gespreek word in die sin van: Is die skuld van die val alleen vir rekening 
van die mens? Hoe moet ons die menslike verantwoordelikheid by die sondeval verklaar?

Dit skyn nie asof een van hierdie rigtinge geslaag het om 'n oplossing te gee nie. Dijk sê dat die Supralapsarisme alles van Gods kant af besien en Berkouwer spreek hiervan as aprioriese soewereiniteit. Die Infralapsarisme redeneer weer vanuit die standpunt van die mens. Bavinck sê dat Spanheim altyd gesê het dat hy op die preekstoel Supralapsariër was, maar Infra- as hy sy gemeente leer. Daar is niks te kiese tussen die twee nie. Albei staan voor groot probleme en kan skriftuurplekke aanvoer vir sy standpunt. Bavinck beweer (Dogm. II 347) „Het Infralapsarisme verdient lof om zijne bescheidenheid, hij geeft geen oplossing maar blijft bij de historische, causale orde staan, het schijnt minder hard en rekent meer met de eischen der praktijk".

Welke is die groot probleem hier? Dit: 'n Mens kan nie uit Gods besluit tot die val kom nie, of alle skuld en verantwoordelikheid van die mens gaan weg. 'n Mens kan ook nie uit die val tot Gods besluit kom nie, of die Raadsbesluit gaan tot niet en Gods vrymag word aangetas. 'n Mens kan ook by 'n ewige God en sy ewige besluite immers nie spreek van 'n vóór en 'n ná nie, omdat 'n mens dan die tydsorde op die ewigheid toepas. Ons verkry hier ook dan die gevaar dat God totaal vermenslik kan word.

Ons geloofsbelydenisstukke staan op Infra-standpunt en die enigste rede is skynbaar omdat dit 'n geloofsbelydenis is en nie 'n wetenskaplike karakter vertoon nie. 'n Geloofsbelydenis dra tog immers 'n sterk persoonlike stempel en die persoon word gekonfronteer met dit wat hyself glo, vir homself aanneem in die geloof. Hiervoor is die Infrabesonder geskik, juis omdat wanneer gespreek word van predestinasie, die skuld en verlorenheid nooit buite die gesigsveld geraak nie. Hier word nie in abstracto geredeneer oor die besluite van God nie, maar is die saak van die heil van die sondaar meer op die voorgrond. Dit gaan nie om die moontlikheid van die saligheid van die mens nie, maar die werklikheid en die betrokkenheid van die mens daarby.

Nou kan ons begin tower met die woord „toelating"'. Sonde geskied dan onder toelating van God. Maar dan vergeet ons dat sonde waarlik nooit buite Gods Raad en voorsienigheid gedink kan en mag word nie. Toelating is geen towerwoord nie en het nog telkens sy kwota probleme ook opgelewer.

Ons wil hiermee volstaan en alleen aandui dat sonde nooit buite die mens gedenk kan word nie. Dit is waarskynlik die fout van Infra en Supra dat dit van sonde 'n abstraksie maak en eintlik altyd sonde in sy verband tot God wou sien. Dan word dit uiters moeilik. Dan word gevra: wat is die oorsprong, die oorsaak van die sonde? Hier kan alleen negatief bepaal word: God is nie die oorsaak nie. ' $n$ Tweede rigting is dat sonde nie 'n selfstandige mag of entiteit naas God gemaak kan word nie. Eintlik behoort dit al genoegsaam rede te wees om te waarsku dat daar verband is sonde en ongehoorsaamheid en dat sonde die mens volgens die Skrif volkome verantwoordelik stel voor God. Sonde bring skuld en skuld moet betaal word. 
Vandaar dat die mens in sy sonde te staan kom voor Gods gerig. Hy moet hom verantwoord. God skenk in Christus voldoening en betaling. Dit is genade.

As die menslike verantwoordelikheid dus by die sonde beklemtoon moet word om so sy verband tot God duidelik te sien en Gods genade duidelik te ontvang, laat ons dan ook hierin, nl. in Gods genade, die probleem van verantwoordelikheid besien.

\section{GODS VERBOND VAN GENADE EN MENSLIKE VERANTWOORDELIKHEID.}

Hier moet gestel word dat onder menslike verantwoordelikheid verstaan word: is die mens lydelik by die wedergeboorte, gaan dit maar net om hom of het hy daar ook 'n Godgegewe roeping? Word die mens wederbaar of is hy wedergebore? Is dit 'n Goddelike daad in die tyd of in die ewigheid? Hoe verklaar ons die mens se verpligting tot geloof en bekering, en wat is die werking van die evangelie en die prediking daarvan?

Sprekende oor Gods genadeverbond, moet ons onthou dat die Dogmatiek met verskillende begrippe werk, almal om dade van God mee te beskryf, en hulle is ten nouste met mekaar verbonde. Ons noem hier: uitverkiesing, wedergeboorte, genadeverbond, bekering. Besonderlik kom die eerste drie hier ter sprake.

Dit is ons nie te doen om 'n noukeurige beskrywing van elkeen se draagwydte en plek te gee nie. Ons kan tog seker wel bepaal dat uitverkiesing, genadeverbond en wedergeboorte mekaar nogal oorvleuel, sodanig dat die een sonder die ander nie denkbaar is nie. 'n Uitverkorene moet ' $n$ wedergeborene wees en in die genadeverbond ingesluit.

Tog het daar na vore gekom die vraag: wat is nou die eerste, uitverkiesing of oprigting van die genadeverbond en hoe moet die wedergeboorte in hierdie verband gesien word?

Nou kan ons wel beweer dat dit nie die grootste van teologiese probleme kan wees nie en dat dit niks te doen het met menslike verantwoordelikheid nie, omdat dit almal Goddelike werkinge is

Ons moet egter nie vergeet nie, dat al hierdie dade juis met die mens gedoen word. Sonder die sondige mens sou elkeen van hierdie dade sinloos gewees het. Dit moet duidelik wees dat Gods uitverkiesing in die ewigheid plaasgevind het, maar het God ook 'n verbond opgerig in die ewigheid? Kan daar 'n verbond opgerig word met 'n party wat nie bestaan nie?

Ons kom dan tot die vraag: Moct ons die genadeverbond stel onder beheersing van die ewige uitverkiesing, sodat as daar gevra word: wie is bondelinge, geantwoord moet word: die uitverkorenes, want met hulle is 'n ewige genadeverbond opgerig.

Kuyper beweer dat die essensie van die verbond monopleuries is maar dit word dupleuries. Ook Bavinck beweer dat wanneer God en mens 'n verbond sluit tree die monopleuriese karakter daarvan sterk op die voorgrond, omdat dit nie gelyke partye is in die verbond nie. God is soewerein, hoog verhewe en is die waarborg vir die voortsetting van die verbond. 
Tog lê hier juis die probleem wat des te meer indringend ondersoek moet word. Dit is gepas dat met eerbied beweer word dat die essensie van die verbond monopleuries is, maar hoe word dit dupleuries? Kuyper sê dit word cupleuries as Cod ans vermoëns herskep om in Hom te glo, Hom te gehoorsaam. Nou word ons geensins gelykwaardig aan God nie en essensieel het die mens nie verander nie. Waarom het die verbond juis nou van essensie verander? Bavinck spreek gelykluidende taal. "Het verbond der genade is daarom wel monopleurisch, het gaat van God uit .... Maar het is bestemd, om dupleurisch te worden, om in de kracht Gods door den mensch bewust en vrijwillig aanvaard en bewaard te worden" (Ger. Dogm. III, 211). En tog, nieteenstaande hierdie duidelike uitspraak bly die saak van die eensydige karakter van die verbond hinder. Hierdie selfde dogmatici stel dit duidelik „En in dat gansche werk der zaligheid komt er van het begin tot het einde niets in van den mensch. Het is Gods werk geheel en alleen ..... Maar des te meer is het van belang, om op te merken, dat deze leer des verbonds, in weerwil dat zij, of liever juist omdat zij in het werk der zaligheid Gods souvereiniteit zoo zuiver en ten volle handhaaft, tegelijkertijd de redelijke en zedelijke natuur des menschen op zoo schoone wijze tot haar recht doet komen".

Laat ons nie hier spreek oor die pactum salutis nie, maar wel oor die foedus gratiae, want in die eersgenoemde het ons die ewigheidswerk van 'n drie-enige God. Hierdie ewige besluit is en bly louter Gods werls en die ver- bond van genade word opgerig, gehandhaaf en uitgevoer deur God alleen. Maar die pactum salutis „breidt zich uit tot een foedus gratiae ..... en daarom treedt het aanstonds bij zijne promulgatie ook op met den eisch van geloof en bekeering" (Geref. Dogm. III p.211).

'n Verbond het essensieel twee partye. Met so 'n bewering wil ons dus geensins die grootheid van God aantas en doen asof die mens medeseggenskap by die oprigting van die verbond moet ontvang nie. Ons wil juis Gods genade verheerlik in die bewering dat dit tot ewige lof van Gods genade moet wees dat God tot die mens afdaal en met hom ' $n$ verbond sluit. Nou is God hierin die Eerste, maar Hy sien die mens aan in sy sonde en as trouelose en maak hom ' $n$ tweede in hierdie verbondsbetrekking. In Gen. 17:7 is God die spreker: „En Ek sal my verbond oprig tussen $\mathrm{My}$ en jou en jou nageslag na jou in hulle geslagte as 'n ewige verbond, om vir jou ' $n$ God te wees en vir jou nageslag na jou". Godsdiens dra die karakter van ' $n$ verbond. $D i t$ is gemeenskap tussen God en mens ,waarin God niet alleen, maar ook de mensch zijne zelfstandigheid als redelijk en zedelijk wezen behoudt en met zijne plichten ook rechten ontvangt" (Geref. Dogm. 184).

En so sien ons Bavinck worstel met die gedagte van die verbond en sy karakter. Inderdaad, as Gods volk die verbond verbreek, daaraan ontrou word, dit ontheilig, nie daarin wandel nie ja, dan word die verbond nie vernietig of opgehef nie. Dit lê vas in Gods ontferminge. God straf die verbondsbre- 
kers en bring oordele oor sy volk. Eintlik moes God die verbond vernietig het, maar dat $\mathrm{Hy}$ dit nie gedoen het nie, is enkel ontferming.

Maar dan, as die verbond verbreek kan word en die verbrekers deur God gestraf word, is hierdie verbond dan nie inderdaad tweevoudig nie? Dat God ons as sondige mense daarin wou betrek, ons en ons nageslag in neerbuigende goedheid wou neem in sy gemeenskap en ons nie wou vernietig nie, dan word die tweevoudigheid van die verbond tog besonder benadruk.

Gods genadeverbond is nog lank nie genoegsaam in sy essensie deurvors nie. Is dit moontlik om te spreek van ,eers mono- en daarna dupleuries"? Dit is waar dat God so aanbiddingswaardig groot is en enige verhouding wat dit God behaag daar te stel is só misterieus en majesteitlik, dat dit bykans onmoontlik is om daaroor nog iets te sê. Maar is die fout nie juis dat ons die majesteit nou lê in die verbond en dan bepaal dat dit eers monopleuries is nie. Die majesteit lê nie in die verbond as sodanig nie, maar in God. In al Gods dade is daar ook Goddelike majesteit, maar hierdie majesteit moet juis daarin geleë wees dat God nooit en nimmer sy mens as tweede oorsaak vernietig nie en ook nooit verdinglik nie. Inteendeel is dit juis hier die majesteitlike dat in die Goddelike daad die mens geaktiveer word en sy verantwoordelikheid benadruk word. Dit is juis waar die nadruk meer moet val: opdat die mens meer deurdring word van Gods genade en heerlikheid, dat dit Hom behaag het om ons in sy genadeverbond te neem. Dit maak hierdie verbond soveel heerliker en bring God soveel nader in ons lewe.

\section{DIE WEDERGEBOORTE EN MENSLIKE VERANTWOORDELIKHEID.}

Hulle wat soos Kuyper en Bavinck die nadruk lê op die monopleuriese wesenskarakter van die verbond, laat die Goddelike verlossingswerk begin in die ewigheid. Ons wil bely dat dit sekerlik juis is. Maar die mens is in die tyd gebore en die deurwerking daarvan in die tyd moet sekerlik sodanig wees dat dit die mens inskakel en nie volkome uitskakel nie. Veral Kuyper is die man wat alles logies deurdink en in 'n magtige eenheidskonsepsie alles daarstel. Hierin is Bavinck nie so aktief en logies nie. Ons wil later daarop meer sê. Eers dan die grootse konsepsie van Kuyper.

Die voorverordinering in die ewigheid is so dat die genadeverbond met Christus opgerig is en in Christus met al sy uitverkorenes. Ook die inskakeling van die uitverkorenes as liggaam van Christus, in Hom één, is nog altyd ewigheidswerk. Christus is Verbondshoof en sy liggaam is sy uitverkorenes. As dit dan so is dat die wedergeboorte alleen die deel kan word van uitverkorenes, is in die ewigheid alles volkome, sodat die wedergeboorte eintlik buite die mens en sonder hom plaasvind. Ons bedoel hier die volstrekte lydelikheid van die mens.

Op die vraag wanneer die wedergeboorte plaasvind, is die antwoord juis nou van besondere waarde: voor of tydens die geboorte. Dit kan vir jare na die geboorte latent bly en so 'n wedergeborene kan nog jarelank in sonde 
bly lewe, maar dan sal na jare die wedergeboorte tog weer na bo kom.

Hier kom ons nou uit die ewigheid in die tyd, juis wanneer Gods ewigheidswerk binne die tyd en binne die mens tot openbaring moet kom. Vind ons nou dat God die mens aktiveer? Ons het tog hier te doen met die kerk en die prediking, met Woord en sakramente. Hoe sien Kuyper die genademiddels se werkinge?

Vir Kuyper is die gepredikte Woord en ook die Heilige Skrif nie aktief by die wedergeboorte nie. $\mathrm{Hy}$ sê in E VOTO II p. 421 (2) „Wanneer we dus van de Heilige Schrift als Woord Gods spreken, is hiermee niet het gansche Woord Gods bedoeld. Bv, niet het Woord Gods waardoor Hij de wereld schiep, of den stormwind doet bedaren, of het ijs smelt, of $u$ den zegen bij $u$ brood geeft, of u ook wedebaart, daar alle deze werkingen uit de Heilige Schrift als zoodanig, en zonder meer, niet voortvloeien". En verder: E VOTO III 411 (2) „Aan deze volstrekte en volkomene lijdelijkheid van den mensch in de wedergeboorte moet deswege ook nu nog zoo stellig mogelijk vastgehouden .... $\mathrm{Ze}$ is niet een natuurlijke, maar een volstrekt bovennatuurlijke daad Gods. Ze heeft dus niets uitstaande met al die andere werkingen Gods waardoor $\mathrm{Hij}$ middellijk op ons werkt, gelijk $\mathrm{Hij}$ dit doet door het Woord, door de sacramenten, door onze levenservaringen, door allerlei ontmoetingen. $\mathrm{Er}$ is in de wedergeboorte geen middellijke werking van wat aard ook. Als God een zondaar ten leven wederbaart, doet $\mathrm{Hij}$ dit rechtstreeksch en onmiddellijk, zonder eenig tusschentreedend instrument.
Hijzelf dringt als de Heilige Geest in ons wezen in, grijpt het in den wortel aan en vernieuwt het in zijn verborgenste kern".

Hoe weet die mens dan dat hy wedergebore is? Dit het tog immers alles nog tot dusver buite hom omgegaan.

In sy GEMEENE GRATIE (Deel II p.213) gee Kuyper hiervan ' $n$ beskrywing. Dit doen egter veelmeer filosofies as teologies aan. Kuyper is die man in sy wysbegeerte van die syn en die denke. Ook hier werk hy met die twee begrippe. Hy sê dat die mens is en dat hy denk. Ons bestaan en ons weet dat ons bestaan. „De mensch ontving een aanzijn en het zelfbewustzijn van dit aanzijn". Nou sê Kuyper dat die wedergeboorte in die wese geskied, in die middepunt. In die wedergeboorte word die geloof ons ook ingeplant. Dit is 'n direkte daad van God, wat onmiddellik plaasvind, sonder Gods Woord en sonder prediking. Dit is Geesteswerk.

Dus ook die geloof, wat nou juis ons bewus moet maak van die wedergeboorte, word ons ingeplant. Uit die wedergeboorte kom die geloof, bekering, heiligmaking na vore, en hiervoor is die genademiddels wel deeglik nodig.

En so beweer Kuyper: vir die syn van die mens se verlossing is die wedergeboorte noodsaaklik. Vir die bewussyn, waartoe ook die geloof behoort, is Gods Woord onontbeerlik. Geloof - in 'n sekere $\sin \ldots$ is 'n bewus word van die heil wat in die wedergeboorte ons deel is.

By Bavinck het ons grotendeels dieselfde gedagtegang as by Kuyper, en tog is hy nie dieselfde gees as Kuyper nie. Miskien moet dit só gestel word 
dat Kuyper so 'n magtige gees was dat dit vir sy tydgenote nie maklik was om teen sy gedagterigting in te gaan nie. Tog is daar enkele duidelike verskille wat eintlik uitlopers is, voelers na 'n nuwe rigting. 'n Mens voel dit aan dat hulle dikwels moeilik inpas by die gedagteloop, juis omdat Bavinck nie kon breek met sy tyd nie en tog was hy so 'n eie persoon met eie stempel dat hy homself ook nie volkome kon onderdruk nie. Bavinck is nie dieselfde gees as Kuyper wat alles, dikwels totaal te veel, verstandelik onder begrip wil bring nie. 'n Mens sou Bavinck ook veel minder 'n metafisiese gees kan noem. Die „syn" waarmee Kuyper werk, vind ons nie as verklaringsgrond by Bavinck nie. So bv. is die hele mens volgens Bavinck betrokke by die wedergeboorte: syn en bewussyn, al sy kragte en vermoëns. Die verandering vind sentraal plaas, in die hart, en daaronder val die hoëre en laere geestesvermoëns (Geref. Dogm. IV 70). En so vind ons gelykheid by Kuyper en Bavinck en tog verskil.

Bavinck het in 1901 en 1902 in De Bazuin artikels geplaas ,die eenige meerdere helderheid zochten te verspreiden over de leer der onmiddellijke wedergeboorte". Hierdie artikels is later in boekvorm uitgegee onder die naam "Roeping en Wedergeboorte".

Hier protesteer Bavinck heftig teen die skeiding tussen wedergeboorte en bekering, wat, so beweer hy, later na vore gekom het en onbekend was toe die Nederlandse Geloofsbelydenis en Heidelbergse Kategismus opgestel is. „En aan eene zekere tegenstelling tusschen den aanvang van het nieuwe leven, als alleen gewerkt door den Heiligen Geest zonder het Woord, en den voortgang van het nieuwe leven, als gewerkt door den Heiligen Geest met het Woord, werd door niemand gedacht" (Roeping en Wedergeboorte p. 55). Hy behandel dan Art. 24 van die Ned. Geloofsbelydenis en Sondag 25 van die Heid. Kategismus en beweer dat die konfessie dit duidelik stel dat die waaragtige geloof in ons gewerk word deur die gehoor van Gods Woord en die werking van die Heilige Gees. Hierby dink die konfessie nie net aan die ontwikkeling van die geestelike lewe nie, maar die begin daarvan, van sy eerste ontstaan af. „De algemeene, gewone voorstelling is deze, dat ook de allereerste aanvang van het geestelijk leven gewerkt wordt door den Heiligen Geest onder gebruikmaking van het Woord des Evangelies" (a.w. p.55).

Bavinck betoog dit duidelik „En van dien aanvang des geestelijken levens in de tweede geboorte belijdt zij nu verder, dat die tot stand komt door het Woord des Evangelies. Niet alleen bij het geloof en de bekeering in dadelijken zin, maar ook bij de wedergeboorte in engeren zin, bij de instorting van het allereerste beginsel des geestelijken levens, is het evangelie volgens onze belijdenis het middel der genade in de hand des Heiligen Geestes (a.w. p. 56).

Swaarwigtig is seer seker die argument „Want indien de wedergeboorte objektief van het Woord werd losgemakkt, zou niet alleen over de tegenwoordigheid en werkzaamheid des Heiligen Geestes niet meer te oordeelen zijn, maar zou ook de conclusie voor de hand liggen, dat Christus' persoon en werk eigenlijk voor de zaligheid niet 
noodig zijn, en dat God den zondaar ook evengoed kon wederbaren zonder Christus" (Gereformeerde Dogmatiek IV p. 54).

Nou is dit waar dat Bavinck naas die middellike wedergeboorte ook nog spreek van 'n onmiddellike wedergeboorte. Hy beweer egter dat die term onmiddellike wedergeboorte nooit by Gereformeerdes gebruik is om die Woord as genademiddel by die wedergeboorte uit te sluit nie. Van onmiddellike wedergeboorte is alleen gespreek om enige Remonstrantse bygedagte hier by die wortel af te sny, asof naamlik die mens se wil 'n skakel moet wees.

En natuurlik vind ons nie van alles 'n volledige verklaring by Bavinck nie. $\mathrm{Hy}$ is tevrede om by talle plekke die onverkenbare misterie te bely en juis omdat God in sy heiligheid en soewereiniteit onkenbaar is, is ook Gods dade nie maklik in begrippe saam te vat nie. Die wonderkarakter van Gods genade moet nie sodanig deur die menslike begrippe verklaar word dat alles daarvan of iets daarvan verlore gaan nie. As aan Bavinck gevra word: hoe word verklaar dat Gods Woord tog aan alle mense gebring word en die aanbidding van die heil van Gods kant algemeen gedoen word en dit ook ernstig en opreg gemeend, en dat almal tog nie die geloof en wedergeboorte deelagtig word nie? antwoord hy eenvoudig: God het dit nie aan ons geopenbaar nie (Geref. Dogm. IV p.6). En as teëgewerp word: hoe moet ons dan Gods dade van ewigheid af verklaar en rym met die woordverkondiging in die tyd? word geantwoord: die evangelie word aan mense verkondig, nie as uitverkorenes of verworpenes nie, maar as sondaars. En: „Het is niet onze taak, maar ligt het voor Gods rekening om deze uitkomst met de algemeene aanbieding des heils in overeenstemming te brengen" (Geref. Dogm. IV p. 4).

Vir elkeen moet dit duidelik wees dat ons in die heilsweg te doen het met stadia wat gewoonlik genoem word: roeping, wedergeboorte, bekering regverdigmaking ens. Die vraag is of daar wel onderskei kan word tussen soveel stadia, of bepaal kan word waar die een begin en die ander eindig. De Groot spreek alleen van drieërlei stadia in die wedergeboorte self: die prinsipiële vernuwing van die hart van die uitverkore sondaar, die voortgesette vernuwing of heiligmaking en die voltooiing $\mathrm{nl}$, in die dag van heerlikheid. Van hierdie drie stadia sou 'n mens die eerste kon verplaas na die tyd vóór die geboorte en die laaste ná die lewenseinde. Die middelste sal dan tog tot hierdie lewe bepaald bly nl. as die sondaar, maar nou wedergebore, toeneem in genade en bevestig word in sy geloof. Die vraag bly tog of dit werklik so gesien moet word: die wedergeboorte word verskuif na die ewigheid en die daaropvolgende heilsweldade word binnegebring in die tyd, met name die bekering en regverdigmaking. Dan sou die mens wel kan meewerk wat betref sy bekering, maar hy is uitgeskakel wat betref die wedergeboorte.

As ons Calvyn lees, vind ons dat hy die wedergeboorte sentraal plaas. In sy Institusie, boek III, hoofstuk 3, handel hy oor die wedergeboorte en gebruik die terme wedergeboorte, bekering, heiligmaking, boetvaardigheid en vernuwing grotendeels deurmekaar. Sy 
saamvattende inhoud bokant hoofstuk 3 lui: „Dat ons deur die geloof wedergebore word. Oor die boetvaardigheid".

Kuyper het in die ewige vastighede vasgegryp. Daar bly egter baie probleme en ons wil hier 'n paar opnoem in die hoop dat ons nog daaroor verder wil spreek:

(i) Wedergeboorte en geloof. Kuyper kon goed daarin slaag om van wedergeboorte as afgehandelde saak te spreek. "Julle is wedergebore uit onverganklike saad". As 'n mens van wedergeboorte spreek as vruggevolg van die prediking van die Woord, bly dit altyd in die teenwoordige tyd. Tog word soms ook wel gespreek van wedergeboorte wat aan die geloof voorafgaan, dus wedergeboorte in engere sin. Die vraag is egter: kan hier temporele onderskeidings gemaak word, hier waar voor en na eintlik nie bestaan nie? Kuyper spreek hier van ewigheidswerkinge, en om dan in die ewigheid te spreek in terme van die tyd, is sekerlik nie denkbaar nie.

(ii) Wedergeboorte en Woord. Hier kan ook nie maar net gespreek word van wedergeboorte deur die Woord nie. Die Woord moet tog eers verstaan word voordat daar 'n werking van kan uitgaan. Die natuurlike mens verstaan nie Gods Woord nie en is dit nodig dat die mens eers in die regte posisie ten opsigte van die Woord moet staan.

Ook hier moet ons aanvaar dat daar in die wedergeboorte onderskei sal moet word. Bavinck beweer ,De wedergeboorte heeft dus plaats onder het Woord, bij het Woord, met het Woord, manr geschiedt niet door het Woord, in dien zin, dat de Heiligen Geest alleen door dat Woord heen zou inwerken in het menschelijk hart" (Roeping en Wedergeboorte p. 220). Hy bedoel hiermee om aan te dui dat die Woord geen magiese krag besit nie, maar dit moet geneem word as voorwaarde waaronder, die geleentheid waarby, die weg waarin God sy genade aan die sondaar verheerlik.

Hier kom wel 'n eksegetiese kwessie na vore en wel omdat 1 Petrus 1:23-25 ons in die moeilikheid plaas en ook omdat die eksegese wat Bavinck van hierdie gedeelte self gee, enersyds in sy Gereformeerde Dogmatiek IV 19 v. en in sy Roeping en Wedergeboorte pp. 233 vv. nie volkome dieselfde rigting gaan nie. „Want julle is wedergebore nie uit verganklike sand nie, maar uit onverganklike, aleur die lewende Woord van God wat tot in ewigheid bly". Die apostel Petrus sluit hierdie gedeelte af in vs. 25 met die woorde "En dit is die woord wat aan julle verkondig is". Nou is ons probleem hier die verband tussen woord en wedergeboorte. As Bavinck hierbo beweer dat die wedergeboorte plaasvind nie deur die woord nie, staan hier tog wel iets anders nl. julle is wedergebore deur die lewende woord van God. Hier moet verband gevind word tussen die „onverganklike saad" en die ,woord". In sy Dogmatiek stel Bavinck dit so: „Het verband doet dus vermoeden, dat zaad en woord dezelfde zaak aanduiden, en dit vermoeden wordt daardoor versterkt, dat in vs. 24 , 25 in het geheel niet meer van het zaad gesproken wordt, maar dat het als gras vergankelijke vleesch aan het woord alleen wordt tegengesteld. Wijl nu deze wedergeboorte te danken is aan God, 
die ze tot stand bracht door de opstanding van Christus en door middel van het levende woord, daarom is $\mathrm{zij}$ eene wedergeboorte-tot-levende-hoop".

In sy Roeping en Wedergeboorte onderskei Bavinck tussen wedergeboorte in engere sin, nl. die instorting van die beginsel van die nuwe lewe en van 'n ander wedergeboorte, nl. wedergeboretot-'n-lewende-hoop. Aan hierdie laasgenoemde ,wedergeboorte-tot-'n-lewende-hoop", gaan die verkondiging van die evangelie dan vooraf.

Bavinck gaan dieper op hierdie eksegetiese kwessie in en hier beweer hy dat daar wel degelik verskil is tussen woord en saad. Dit vind hy al in die voorsetsels. Die gelowiges is wedergebore uit onverganklike saad, maar deur (of: deur middel van) die woord. Die woord is dus middel en die saad die beginsel.

Dit sal seker die moeite loon om hierop nog veel dieper in te gaan. Daar is tog ook noue verband tussen saad en woord. Hulle is albei onverganklik en ewig. 'n Mens kan ook nie willekeurig onderskeidinge tref tussen wedergeboorte in enger sin en weer in ' $n$ ander bepaalde sin, net om jouself uit 'n eksegetiese moeilikheid uit los te wikkel nie. Ons moet ook hier ons konfessie laat meespreek en verwys hier na Art. 24 van die Nederlandse Geloofsbelydenis: "Ons glo dat hierdie waaragtige geloof, in die mens gewerk deur die gehoor van die Woord van God en die werking van die Heilige Gees, hom wederbaar en tot 'n nuwe mens maak . . ...'. Hier word inderdaad geloof, Woord en wedergeboorte in besonder noue verband tot mekaar gestel.

(iii) Wedergeboorte en roeping. Wedergeboorte gaan aan roeping vooraf. Ook hier moet ons elsegeties ons verantwoord. Matth. 22:14 het tog nadere verklaring nodig: „Want baie is geroep, maar min uitverkies". Ons het hier te doen met woorde aan die slot van die gelykenis aangaande die genooides na die bruilof. Hier moet seker onderskei word tussen genoemde roeping en die roeping waarvan die apostel Paulus spreek in Rom. 8:30 „Die wat Hy vantevore verordineer het, die het $\mathrm{Hy}$ ook geroep".

By die roeping kom ook die verband tot die Woord van God en die bediening van die Heilige Evangelie. Inderdaad moet hier ook besinning kom, juis omdat die mens ook as sondaar hier getrek word uit die duisternis tot die lig.

Die misterie is die lewenselement van die Dogmatiek, veral as die verhouding van God tot die sondaarmens ter sprake kom. Die evangelie van vergiffenis wat tog so ryk is en so troosryk, het sy baie probleme. Hy moet sy vastighede nie prysgee en gaan ronddobber nie. Hy moet die mens en sy verantwoordelikheid nie loslaat en die indruk wek dat van die mens se kant daar maar onverskilligheid en onverantwoordelikheid mag wees nie. Hy mag die ewigheid nie loslaat ten gunste van die tyd nie en hy mag die tyd nie loslaat en net by die ewigheid hom bepaal nie. Veral is daar behoefte aan besinning oor die begrippe en hul draagwydte, die wat ons in die verlede altyd gebruik het. In die besef dat in Gereformeerde kringe daar al baie stryd ontstaan en gevoer is, 
juis oor hierdie dinge, kan ons miskien terugdeins. Tog is daar nie minder ernstige gevare wat dreig van die kant van die metodisme nie.

S. P. v. d. WALT. 